\title{
Insights into the evolution of digestive systems from studies of Trichoplax adhaerens
}

\author{
Carolyn L. Smith ${ }^{1}$ (1) $\cdot$ Tatiana D. Mayorova ${ }^{1}$
}

Received: 13 February 2019 / Accepted: 9 June 2019 / Published online: 3 July 2019

(C) The Author(s) 2019

\begin{abstract}
Trichoplax, a member of the phylum Placozoa, is a tiny ciliated marine animal that glides on surfaces feeding on algae and cyanobacteria. It stands out from other animals in that it lacks an internal digestive system and, instead, digests food trapped under its lower surface. Here we review recent work on the phenotypes of its six cell types and their roles in digestion and feeding behavior. Phylogenomic analyses place Placozoa as sister to Eumetazoa, the clade that includes Cnidaria and Bilateria. Comparing the phenotypes of cells in Trichoplax to those of cells in the digestive epithelia of Eumetazoa allows us to make inferences about the cell types and mode of feeding of their ancestors. From our increasingly mechanistic understanding of feeding in Trichoplax, we get a glimpse into how primitive animals may have hunted and consumed food prior to the evolution of neurons, muscles, and internal digestive systems.
\end{abstract}

Keywords Placozoa $\cdot$ Porifera $\cdot$ Enterocyte $\cdot$ Enteroendocrine $\cdot$ Mucocyte

\section{Introduction}

The origin of the gut may represent the most important innovation in metazoan history, leading to coevolutionary arms races that some workers have hypothesized are the ultimate cause of the Cambrian radiation. Sperling and Vinther (2010) Dev. Evol. 12: 201.

All animals on earth today are descendants of a cell or colony of cells that lived over 600 million years ago. The cell/s probably resembled choanoflagellates, eukaryotic cells that are the closest sister to Metazoa (Brunet and King 2017; Cavalier-Smith 2016; King 2004; King et al. 2008; Nielsen 2008). Choanoflagellates possess a motile cilium surrounded by a collar of microvilli linked together by distinctive vanes. Beating of the cilium draws

Electronic supplementary material The online version of this article (https://doi.org/10.1007/s00441-019-03057-z) contains supplementary material, which is available to authorized users.

Carolyn L. Smith

smithca@ninds.nih.gov

1 National Institute of Neurological Disorders and Stroke, National Institutes of Health, Bethesda, MD 20892, USA bacteria into the collar, where they are endocytosed and digested intracellularly (Dayel and King 2014).

Porifera, long thought to be the most ancient animals (although see Dunn et al. 2008; Moroz et al. 2014; Ryan et al. 2013; Whelan et al. 2017; Whelan et al. 2015), are sessile filterfeeders. Their bodies are perforated by a system of aquiferous canals with openings to the external surface through which water can flow in or out. Choanocytes, a type of cell in the lining of their canals, resemble choanoflagellates in that they possess an apical cilium surrounded by a collar of microvilli with interconnecting vanes (reviewed by Brunet and King 2017; Mah et al. 2014). The cilia are motile and their beating generates water currents that carry bacteria into the canals where they are endocytosed and digested intracellularly by choanocytes and other cells that line the canals (Leys and Eerkes-Medrano 2006).

Choanoflagellates and most Porifera only can eat organisms that are much smaller than a eukaryotic cell. Other animals evolved mechanisms for extracellular digestion, which opened the way to feeding upon larger prey (reviewed by Fankboner and Columbia 2002; Monk and Paulin 2014; Nielsen 2012; Peterson et al. 2012; Sperling and Vinther 2010; Yonge 1937). Ctenophora, Cnidaria, and Bilateria ingest food through their mouths into an internal digestive system whose lining contain cells that secrete digestive enzymes to breakdown food and absorptive cells that take up the products of digestion. The digestive systems of most animals also 
include sensory/endocrine cells that secrete a chemical signal such as a peptide, hormone, or neurotransmitter, cells that secrete mucous and contractile cells (reviewed by Fankboner and Columbia 2002; Harrison and Westfall 1991; Takashima et al. 2013). The digestive epithelium and the muscles associated with it are innervated by an enteric nervous system that is separate from, but communicates with, the nervous system that receives sensory input from outside the animals and controls the somatic musculature (Furness and Stebbing 2018; Kaelberer et al. 2018).

The evolution of animals with internal digestive systems, muscles, and nervous systems required numerous innovations. No fossil has been found that could represent an animal at an intermediary stage in this process (reviewed by Droser and Gehling 2015; Erwin 2015). However, there are extant animals whose body plan and lifestyle might be similar to such an animal. They are members of the phylum Placozoa (reviewed by Arendt et al. 2015; Knoll 2011; Nielsen 2008; Schierwater 2005; Sperling and Vinther 2010).

Placozoa are small, flat, ciliated animals that glide on substrates in warm oceans feeding on cyanobacteria and microalgae, which they digest externally in the narrow space between their lower epithelium and the substrate (Grell and Ruthmann 1991; Schulze 1891; Smith et al. 2015). They possess just six morphologically distinct cell types (Smith et al. 2014), fewer than any other animals except some larval or parasitic animals. Although they lack neurons and muscles, they display coordinated behavior during feeding (Smith et al. 2015) and are capable of chemotaxis (Smith et al. 2019).

Trichoplax adhaerens, discovered and named by Franz Schulze (1883), is the best known member of the phylum. Several additional haplotypes have been identified by sequencing genes from placozoans collected from oceans in different parts of the world (Eitel et al. 2018; Pearse and Voigt 2007; Signorovitch et al. 2006; Voigt et al. 2004). Comparison of the genome of Trichoplax with that of another placozoan, Hoilungia hongkongensis, revealed that they differed by a degree corresponding to different genera in other basal metazoan phyla (Eitel et al. 2018). However, all placozoans that have been studied so far have the same morphological cell types and similar body plans (Eitel et al. 2018; Guidi et al. 2011; Smith et al. 2014) and they exhibit the same behaviors during feeding (Smith et al. 2015; Ueda et al. 1999). A clone of Trichoplax established by Karl Grell (Grell 1971) has been the subject of most research on Placozoa. Placozoans propagate by fission in the laboratory, and consequently, almost nothing is known about their embryology. However, there is morphological and molecular evidence of sexual reproduction among placozoans (Eitel et al. 2011; Grell and Ruthmann 1991; Signorovitch et al. 2005).

Phylogenetic trees based on comparative anatomy placed Porifera as the oldest metazoan phylum and Placozoa as second oldest (reviewed by Dohrmann and Wörheide 2013;
Nielsen 2012). Cnidaria, Ctenophora, and Bilateria were thought to have diverged later. More recent analyses based on phylogenomics have challenged this view with some studies concluding that Ctenophora is the oldest phylum and Porifera second oldest, or vice versa (reviewed by King and Rokas 2017). Although the phylogenetic placements of Ctenonphora and Porifera continue to be debated, most analyses agree that Placozoa is sister to the clade that includes Cnidaria and Bilateria (Dunn et al. 2008; Moroz et al. 2014; Pett et al. 2019; Ryan et al. 2013; Simion et al. 2017; Srivastava et al. 2008; Whelan et al. 2017, 2015).

Here we review recent work elucidating the body plan, cell types, and feeding behavior of Trichoplax. Comparing the phenotypes of cells in Trichoplax to those of cells in the digestive epithelia of other animals allows us to make inferences about the cell types and mode of feeding of their ancestors. From the biology of Trichoplax, we get a glimpse into how primitive animals may have hunted and consumed food prior to the evolution of neurons, muscles, and internal digestive systems.

\section{Overview of body plan and cell types}

Trichoplax are about a millimeter in diameter but only about $20 \mu \mathrm{m}$ thick. Their shapes are irregular and constantly changing; they have no axis of symmetry. Our description of their body plan and cell types is based on studies of animals prepared by freezing and freeze substitution (Buchholz and Ruthmann 1995; Eitel et al. 2018; Ruthmann et al. 1986; Smith et al. 2014) because these procedures preserve the cells better than chemical fixation (Grell and Ruthmann 1991; Grell and Benwitz 1971; Guidi et al. 2011). A schematic view of a cross section near the edge of the animal (Fig. 1) illustrates the locations and shapes of its six cell types. The columnar epithelium on the ventral side of the animal, the side that faces the substrate, contains three types of cells: (1) cells with a motile cilium and microvilli on their apical ends, referred to here as ventral epithelial cells (VEC); (2) lipophil cells, so named because of their content of large lipophilic granules; and (3) gland cells, a generic name used for secretory cells with smaller granules. The dorsal epithelium is paved by polygonal apices of flask-shaped cells whose cell bodies protrude below. In between the dorsal and ventral epithelium is a layer of cells with long branching processes, known as fiber cells. Crystal cells, which are reported to be gravitysensing cells (Mayorova et al. 2018a) also are located in the interior layer, but only near the edge of the animal.

All cells in the epithelium are joined by apical belt junctions that manifest features of adherens junctions in epithelia of Eumetazoa (Cnidaria plus Bilateria; Ruthmann et al. 1986; Smith and Reese 2016). Membrane appositions marked by periodic material in the intercellular cleft often are present beneath the apical adherens junctions, but these do not represent true junctions because they separate in animals treated with 
Fig. 1 Schematic diagram of Trichoplax cell types and body plan. The ventral epithelium contains monociliated ventral epithelial cells (VEC), lipophil cells that contain large lipophilic inclusions, and, near the edge, gland cells with secretory granules. Dorsal epithelial cells (DEC) pave the dorsal surface. In between the dorsal and ventral epithelia are fiber cells with branching processes. A crystal cell containing a birefringent crystal lies under the dorsal epithelium near the left edge. Reproduced from (Smith et al. 2014) copyright 2014 with permission from Elsevier

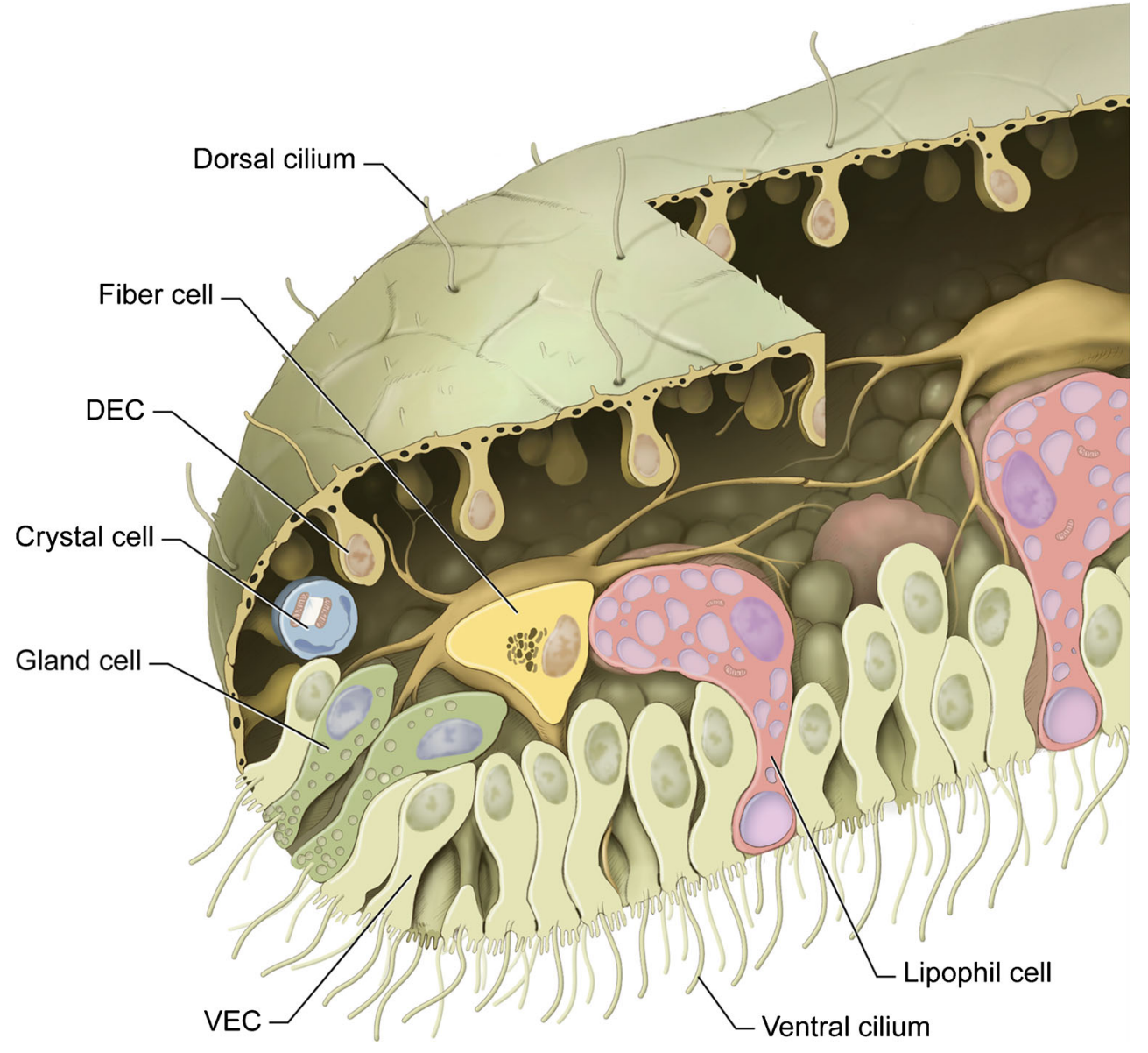

hypertonic seawater; only the adherens junctions remain intact (Smith and Reese 2016). The adherens junctions fix the positions of cells relative to one another but provide only a leaky barrier to diffusion of molecules through the intercellular gaps. Molecules smaller than $10 \mathrm{kDa}$ rapidly diffuse through the junctions and into the interior of the animal. Gap junctions are common among epithelial cells in Ctenophora, some classes of Cnidaria and Bilateria, but gap junctions are not present in Placozoa and no panexins/innexins have been found in their genomes (Eitel et al. 2018; Moroz and Kohn 2016; Srivastava et al. 2008). Fiber cells are interconnected by infrequent syncytial junctions where the membranes of adjoined cells are continuous but their cytoplasm separated by an electron dense septum (Buchholz and Ruthmann 1995; Grell and Benwitz 1974; Smith et al. 2014). These junctions resemble syncytial junctions in Hexactinellid sponges, which are electrically coupled (Mackie and Singla 1983), and the colonial choanoflagellate Salpingoeca rosetta (Dayel et al. 2011).

\section{Feeding behavior}

The gliding motility of Trichoplax is propelled by the cilia of VEC, which beat regularly, but asynchronously, and transiently contact the substrate during each stroke (Smith et al. 2015). Trichoplax migrate aimlessly when cultured on a uniform lawn of algae or artificial food. Their trajectories resemble those of random walkers (Ueda et al. 1999). However, in the presence of a focal concentration of food, they exhibit chemotaxis, moving preferentially in the direction of the food (Smith et al. 2019). Chemotaxis toward a focal concentration of glycine also has been reported (Heyland et al. 2014). Chemotaxis has been proposed to arise from directed movement of the ciliated VEC, each independently sensing and responding to the chemoattractant (Smith et al. 2019).

When a gliding animal encounters food, it gradually slows down and then, quite suddenly, becomes almost completely stationary (Smith et al. 2015). Pausing is accompanied by arrest of ciliary beating. The initiation of digestion is evident in fluorescence images because the lysed algae release fluorescent phycoerythrin (Fig. 2, Online resource, Movie 1). Feeding is accompanied by rapid churning movement of fiber cells (Online resource, Movie 1) and ventral epithelial cells (Online resource, Movie 2) in the vicinity of the lysed algae. The churning movements of the ventral epithelial cells may help to distribute the material released from the lysed algae. Then 
Fig. 2 a-f Trichoplax feeding on Rhodomonas algae. Algae appear as tiny red specks due to their content of fluorescent phycoerythrin. At 8 to $24 \mathrm{~s}$, groups of algae under the paused Trichoplax release their contents, indicating that they have been lysed by digestive enzymes secreted from the animal. Note that the animal is stationary during feeding. At 408 to $440 \mathrm{~s}$, the animal has crawled over a fresh patch of algae and again pauses to feed. Merged transmitted light and fluorescence images (543-nm illumination) from a confocal microscope. Scale bar $-200 \mu \mathrm{m}$. Reproduced from (Smith et al. 2015)
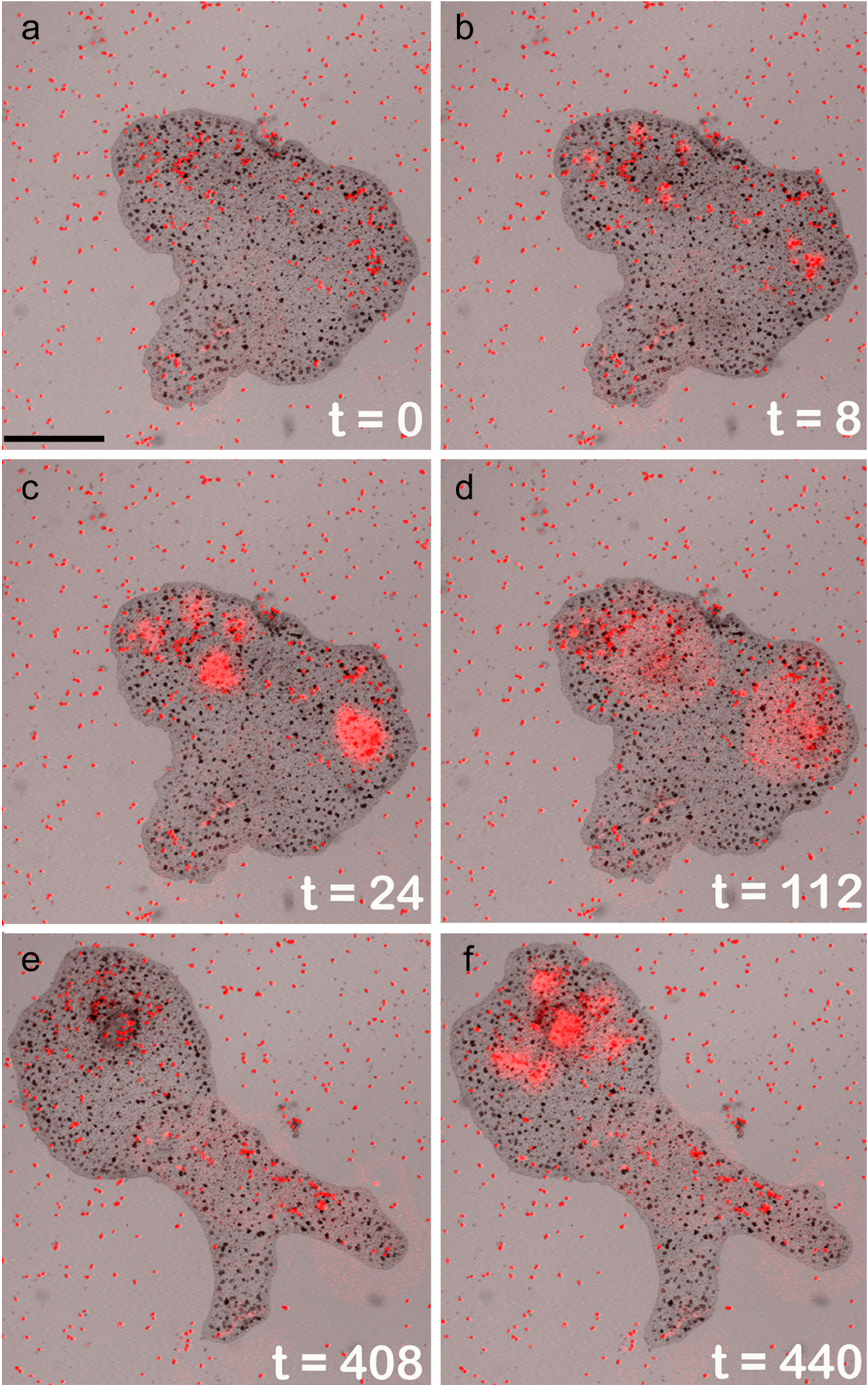

more widespread groups of cells begin slow undulatory movements while cells near the edge remain largely stationary. Finally, the animal begins gliding again, slowly at first and gradually resuming its typical speed of migration.

\section{Absorptive cells}

The absorptive cells have been identified by visualizing uptake of tracers such as ferritin (Ruthmann et al. 1986), 
horseradish peroxidase (HRP), and fluorescent dextrans (Smith and Reese 2016). The tracers are rapidly endocytosed by ciliated VEC. The presence of coated pits on exterior surfaces of VEC suggests that uptake involves clathrin-mediated endocytosis. The endocytic vesicles increase in size over time, probably due to fusion with other vesicles. Over the course of days, fluorescent dextrans appear in vesicles in other cell types, suggesting the presence of mechanisms for transcytosis (C. Smith, unpublished).

Trichoplax VEC resemble choanoflagellates, choanocytes of Porifera and the absorptive cells in the digestive epithelia of Ctenophora, Cnidaria, and many Bilateria (lower deuterostomes and lophotrochozoans) in that they have a motile cilium surrounded by microvilli (Goldberg and Taylor 1989; Harrison and Westfall 1991; Nielsen 2012; Takashima et al. 2013). Cilia in these animals propel fluid flow, rather than serving for locomotion as in Trichoplax. Ciliated cells are found in many eukaryotic taxa, but cells with an apical cilium surrounded by microvilli are present only in Choanozoa (reviewed by Brunet and King 2017), the clade that includes Choanoflagellates and Metazoa.

Ciliated absorptive cells, including those in Trichoplax, endocytose the nutrients released from food by the action of extracellular digestive enzymes and digestion is completed intracellularly via the lysosomal pathway. In most chordates and ecdysozoans, food is broken down into molecules by extracellular digestive enzymes and the molecules are taken up by transporters rather than by endocytosis (reviewed by Takashima et al. 2013). The absorptive cells in these animals generally lack a cilium and instead have numerous, long microvilli.

\section{Lipophil cells secrete digestive enzymes}

Lipophil cells are uniformly distributed across the ventral epithelium, but are absent in a $100-\mu \mathrm{m}$ wide region near the rim (Smith et al. 2014). Their granules are visible in living animals due to their uptake of fluorescent lipophilic and acidophilic dyes. After an animal has crawled onto a patch of algae and paused, lipophil cells in the close vicinity $(<15 \mu \mathrm{m})$ of algal cells secrete a large granule and the contents of these granules lyse the algae within $1 \mathrm{~s}$ (Fig. 3; Online resource, Movie 2).

Lipophil cells in different parts of the animal secrete a granule at about the same time. The accurate targeting of the secretory events suggests that a yet to be identified cell type detects algae and triggers secretion from nearby lipophil cells, while the temporal coordination of secretory events in different parts of the animal would seem to require a mechanism for long-range communication.

Lipophil cells viewed in thin sections from samples prepared by freezing and freeze substitution have numerous large granules throughout their interior with one very large granule $(\sim 3 \mu \mathrm{m})$ in close apposition to the apical plasma membrane (Fig. 4; Smith et al. 2015). Only the large granule is secreted during feeding. The content of the granules for the most part is electron lucent although patches of dark material often are present (Fig. 4a, b). The pale areas may have lost their contents during freeze substitution as the content appears more uniformly electron dense in cryosections from rapidly frozen samples (Fig. 4c).

Gastrodermal cells that secrete digestive enzymes in Cnidaria and Bilateria contain zymogen granules whose content appears dark and homogeneous in thin sections from chemically fixed material (reviewed by Goldberg and Taylor 1989; Harrison and Westfall 1991; Takashima et al. 2013). Zymogens are the packaged precursors of digestive enzymes (Tang 1979; Tang and Wong 1987). Analyses of the Trichoplax proteome (Ringrose et al. 2013) and transcriptome (Wong 2018) showed high expression of the precursors of digestive enzymes such as trypsin, chymotrypsin, and carboxypeptidase $\mathrm{D}$, which are utilized for both intracellular and extracellular digestion, and phospholipase A2/1B, the type of phospholipase secreted by mammalian pancreatic acinar cells (Pandol 2010). Single-cell RNA sequencing in Trichoplax (Sebé-Pedrós et al. 2018) showed that all of these enzyme precursors are co-expressed in a distinct cell type. Fluorescence in situ hybridization with probes against Trichoplax trypsin, chymotrypsin, and phospholipase A2 confirmed that spatial distribution of cells expressing these enzymes matches that of lipophil cells labeled with a lipophilic dye (C. Smith and T. Mayorova, unpublished observations). There is experimental evidence that lipophilic granules in Trichoplax contain toxins (Jackson and Buss 2009) and several toxins have been identified in the Trichoplax genome (Jackson and Buss 2009; Kim et al. 2018). To our knowledge, lipids have not been detected in digestive granules in animals other than Placozoa. However, digestive cells in many animals contain specialized enzymes for lysing and digesting the particular organisms that they eat (Jouiaei et al. 2015; Navarrete del Toro and García-Carreño 2018; Yonge 1937).

In Ctenophora, food is digested in the oral cavity and pharynx (Bumann and Puls 1997), and it has been suggested that the digestive enzymes may be secreted by a type of cell that contains granules whose content appears finely granular by electron microscopy (Hernandez-Nicaise 1991). Precursors for secreted trypsin/chymotrypsin and carboxypeptidase D have been identified in transcriptomes from Mnemiopsis leidyi and Hormiphora californiensis (A. Senatore, personal communication), but phospholipase A2 has not been found.

\section{Gland cell types}

Three morphologically distinct types of gland cells are evident in the ventral epithelium by electron microscopy (Mayorova et al. 2018b): (1) Type 1 cells, which contain large ( $\sim 500 \mathrm{~nm})$ 
Fig. 3 Lipophil granule secretion in a Trichoplax feeding on Rhodomonas algae. Field of lipophil granules (large orange spheres) stained with an acidophilic dye near a clump of algae and algae debris (yellow-green) prior to (a) and following (b) granule secretion (cyan circles; time interval $308 \mathrm{~ms}$ ). Secreted granules (yellow arrowheads in b) enlarge and become greener due to uptake of a green lipophilic dye. Scale $20 \mu \mathrm{m}$. Reproduced from (Smith et al. 2015)
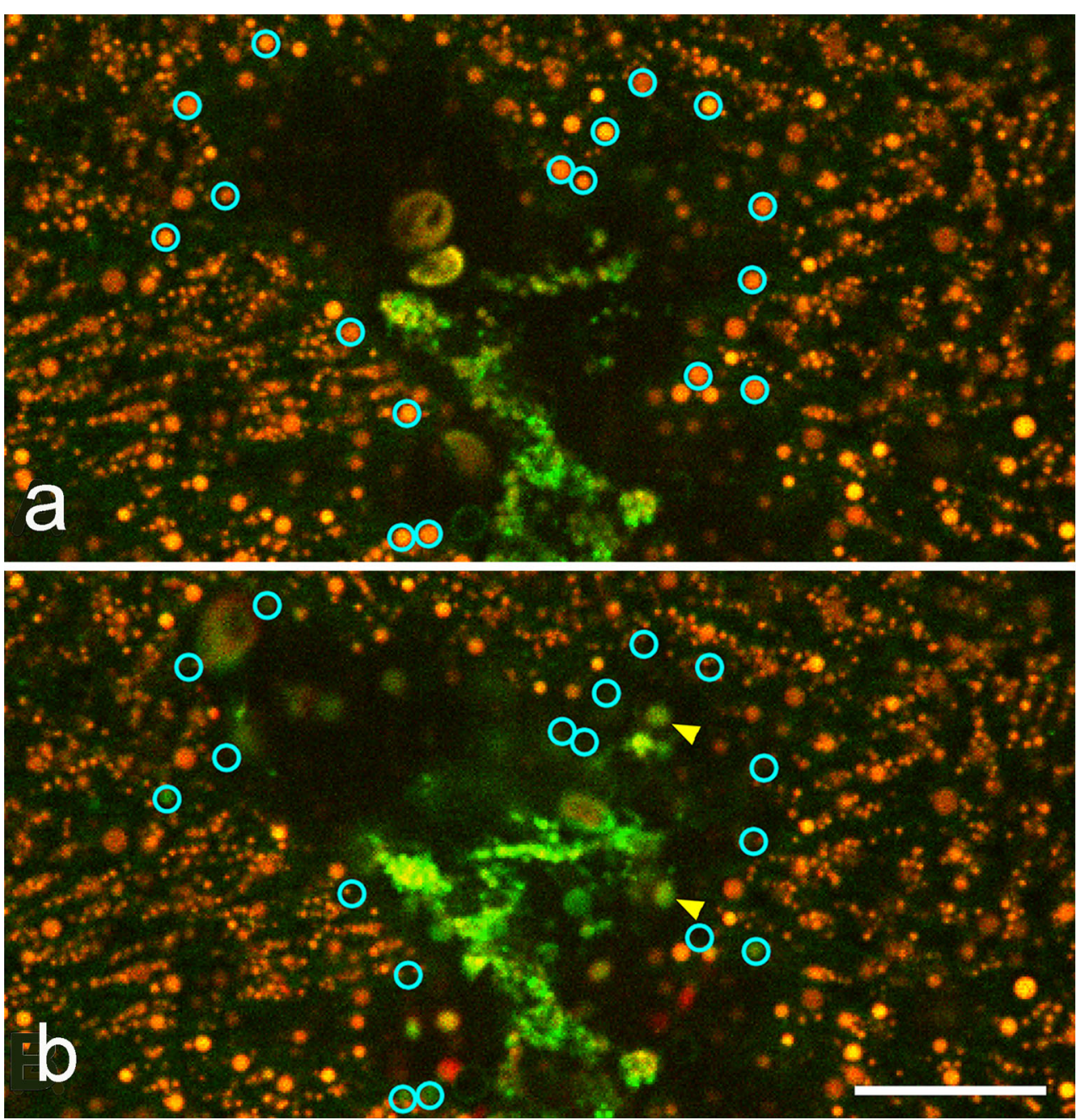

granules whose content appears uniformly dark gray, but sometimes has a dense core. These cells bear an apical cilium and microvilli. (2) Type 2 cells contain electron-lucent granules $\sim 300 \mathrm{~nm}$ in diameter and have apical microvilli but no cilium. (3) Type 3 cells contain light gray granules $\sim 250 \mathrm{~nm}$ in diameter and have both a cilium and microvilli. Each of these cell types has a distinctive distribution within the animal. Recent work demonstrates that the granules of type 2 cells contain mucous and immunolabel for a peptide that arrests ciliary beating when applied to the seawater surrounding a gliding animal, as is discussed below. Several additional types of peptidergic cells have been identified by immunofluorescence (Varoqueaux et al. 2018) and some of them are in positions roughly corresponding with those of type 1 and type 3 gland cells.

\section{Mucous cells}

The entire epithelium of Trichoplax is coated with a thin layer of mucous that binds to wheat germ agglutinin (WGA;
Mayorova et al. 2018b). Gliding animals leave a trail of mucous in their wake and, when they pause to feed, leave a ring of mucous marking the spot where they stopped. Mucous cells are columnar in shape and incorporated in the ventral epithelium. They are most prevalent around the rim of the animal but also present in moderate numbers further inside. Electron microscopy with nanogold-conjugated WGA showed that the lectin was inside the electron-lucent granules of type 2 gland cells. These cells also express voltage-gated calcium channels and proteins involved in calcium-regulated secretion (Senatore et al. 2016; Smith et al. 2014) and some of them label for a neuropeptide (see next section).

Mucocytes are prevalent in the mouths and digestive tracts of Ctenophora, Cnidaria, and Bilateria (reviewed by Harrison and Westfall 1991; Takashima et al. 2013). The mucouscontaining granules are much larger than those in type 2 gland cells and appear irregular in shape and fused together in samples prepared with chemical fixatives (Harrison and Westfall 1991) but are oval and clearly separated in samples prepared by freezing and freeze substitution (Ichikawa et al. 1987; Sandoz et al. 1985). Mucous serves as a vehicle for transport 
of food into the digestive cavity/tract and to expel undigestible material and feces. Mucous also protects the digestive epithelium from harmful molecules, such as digestive enzymes, and microorganisms (Bakshani et al. 2018; Dias et al. 2018; Liévin-Le Moal and Servin 2006). Mucocytes have not been reported in adult Porifera, but mucous-secreting cells are present in larval sponges (Homoscleromorpha-Ereskovsky et al. 2007; Demospongiae-Leys and Degnan 2001). In Oscarella (Homoscleromorpha) larvae, cells at the anterior pole secrete mucous while the larvae are attaching to the substrate prior to metamorphosis.

Gel-forming mucins are the main component of mucous in vertebrates, although mucous includes many additional components. Sequences for proteins with domains (VWD, C8, and Til) characteristic of vertebrate gel-forming mucins have been found in representatives of all metazoan phyla except Porifera (Adams 2013; Lang et al. 2016; Lang et al. 2007). A mucinlike protein with VWD and C8 domains is present in the choanoflagellate, Salpingoeca rosetta (http://www.medkem. gu.se/mucinbiology/databases/). Interestingly, mucin appears to have a role in colony formation in $S$. rosetta because WGA stains the surfaces of colonial cells and cells competent to form colonies, but not solitary cells (Dayel et al. 2011), suggesting that the original function of mucin may have been to mediate cell adhesion.

\section{Peptidergic gland cells}

The first evidence that neuropeptides might have a role in controlling the locomotor activity of Trichoplax came from a study in which animals were bathed with synthetic peptides (Senatore et al. 2017). Two peptides originally identified as endogenous ligands for mu-type opioid receptors in mammalian brain, endomorphin 1 (YPWFamide) and endomorphin 2 (YPFFamide), reliably elicited a pause in gliding accompanied by arrest of ciliary beating. The animal ceased moving $\sim 2$ min after addition of the peptide and remained stationary for about $3 \mathrm{~min}$, similar to the duration of pauses that occur during feeding.

Antiserum against YPFFamide labeled a row of cells near the edge of the animal and a smaller number of cells further in the interior (Fig. 5a). Double labeling with WGA lectin revealed that a large subset of the mucous-containing cells labeled for YPFFamide (Mayorova et al. 2018b). Electron microscopy with immunogold labeling revealed that YPFFamide localized to clear granules of type 2 gland cells. That these mucous-secreting cells immunolabel for YPFFamide supports the idea that they contain a peptide but does not prove that the peptide is YPFFamide because antisera against peptides can cross-react (Conzelmann and Jékely 2012). Indeed, YPFFamide antiserum cross-reacts with
FMRFamide, a neuropeptide found in many invertebrates, and vice versa (Senatore et al. 2017).

Secretory peptides are generated by cleavage and processing of a longer precursor protein, referred to as a prepropeptide (Fricker 2005; Hook et al. 2008; Jékely 2013; Mains et al. 1986). A possible candidate for a YPFF-like prepropeptide (TaELP) was found in a Trichoplax transcriptome (Senatore et al. 2017), but the predicted peptide, QDYPFFGN/S, is not expected to be amidated by the enzyme that converts an $\mathrm{N}$ terminal glycine into an amide (Kumar et al. 2016). Nevertheless, antisera against a unique epitope in the prepropeptide labeled the same population of secretory cells marked by anti-YPFFamide (Fig. 5b, c). Prepropeptide sequences for over a dozen peptides have been identified in Trichoplax (Jékely 2013; Nikitin 2014; Varoqueaux et al. 2018; Wong 2018), and several of the predicted peptides (FFNPamide, ELPE, MFPF, and WPPF) were reported to elicit pausing when applied to the seawater around moving animals (Varoqueaux et al. 2018). WPPF elicited pausing at concentrations $>1 \mu \mathrm{M}$ (compared with $200 \mathrm{nM}$ for YPFFamide), but the latency between application of the peptide and the initiation of pausing was $\sim 7 \mathrm{~min}$, twice as long as the latency for YPFFamide. The latencies for the other peptides were even longer, and higher concentrations were needed to elicit pausing. Whether pauses elicited by these peptides are accompanied by arrest of ciliary beating remains to be demonstrated. At present, a YPPFamide-like peptide is the best candidate for the endogenous peptide that arrests ciliary beating during feeding.

Senatore et al. (2017) hypothesized that YPFFamidecontaining secretory cells are chemosensory cells that secrete peptide upon activation by a signal emitted by algae. Location of the cells near the edge of the animal puts them in a good position to signal that the animal has crawled onto a patch of algae. To explain how a small number of secretory cells could elicit global arrest of ciliary beating, they proposed that the peptide-secreting cells bear receptors for the peptide they secrete. If so, then peptide secreted by a cell that sensed algae would activate secretion by its neighbors, thereby initiating a wave of secretion that would ultimately extend across the entire animal. In support of this suggestion, they cited observations indicating that chemical signals secreted by one animal elicit secretion in nearby animals.

The Trichoplax genome includes homologs of eumetazoan GPCR-type peptide receptors (Jékely 2013; Krishnan and Schiöth 2015; Nikitin 2014) and ionotropic peptide receptors (Assmann et al. 2014). Responses mediated by GPCR are slow whereas those mediated by ionotropic receptors are faster. A rapidly acting type of receptor would seem to be required for communication between the secretory cells but GPCRs could mediate the gradual arrest of ciliary beating.

Interestingly, some sensory cells and neurons in the apical (aboral) organ of Ctenophora (Jager et al. 2011), and in the tentacles and around the mouth of Cnidaria (Anderson et al. 
2004; Grimmelikhuijzen et al. 1991; Koizumi 2016; Koizumi et al. 1992; Marlow et al. 2009; Mayorova and Kosevich 2013; Watanabe et al. 2009) label with antisera against FMRFamide, as do type 2 gland cells in Trichoplax. Similarity-based cluster analyses (Jékely 2013) and BLAST comparisons (Nikitin 2014) of prepropeptides in Trichoplax, Cnidaria, and Bilateria showed that Trichoplax has prepropeptides related to cnidarian and bilaterian Famides, RWamides, and insulin-like peptides. Prepropeptides have been identified in the genomes of Ctenophora but the predicted peptides are thought to be unrelated to those in other animals (Moroz et al. 2014). Porifera apparently do not employ secretory peptides for intercellular communication because no prepropeptides have been detected in their genomes (Francis et al. 2017; Srivastava et al. 2010). However, peptide signaling evolved long before the origin of Metazoa since prepropeptides and the enzymes needed to process them are present in the green algae Chlamydomonas reinhardtii (Luxmi et al. 2018).

\section{Contractile cells}

While Trichoplax feeds on algae, epithelial cells in the vicinity of lysed algae undergo rapid churning movements that may help to distribute the released nutrients (Smith et al. 2015; Online resource, Movie 2). Fiber cells lying above the epithelial cells also churn (Online resource, Movie 1). The processes of fiber cells ramify around and extend between cells in the ventral epithelium (Fig. 6). If their branches are contractile, as has been suggested (Buchholz and Ruthmann 1995; Grell and Ruthmann 1991), it is possible that they generate the churning movements. The processes of fiber cells are packed with filamentous actin, suggesting that they might have an actomyosin contractile apparatus. Although myofibrils have not been observed in fiber cells in ultrastructural studies, they might be difficult to detect if they are not organized into bundles. Dorsal epithelial cells are known to be contractile, but their contractile movements occur independently from cells in the ventral epithelium (Armon et al. 2018), so they are unlikely to be involved in generating the churning movements.

\section{Nature of the common ancestor of Placozoa and Eumetazoa}

Currently, too little is known about the phenotypes of cells in Ctenophora to allow us to speculate about the nature of the ancestor of the clade that includes Ctenophora, Placozoa, Cnidaria, and Bilateria. Based on shared features of Placozoa, Cnidaria, and Bilateria, it appears likely that their progenitor digested food extracellularly and had a digestive epithelium containing absorptive cells with a motile cilium and apical microvilli, cells that secreted digestive enzymes,
Fig. 4 Lipophil cells. a Electron micrographs of lipophil cells prepared by freezing and freeze substitution. They are packed with large granules and have one very large granule (vent gran) closely apposed to the plasma membrane at their apical end. Granules vary in their contents throughout the lipophil. b Deep in the cell body, granules are produced by the Golgi apparatus (lettering indicates probable order). c Unfixed frozen section through a lipophil granule shows that these granules actually have uniformly dense contents. d Live cell imaging of an isolated lipophil cell stained with a red lipophilic dye showing that granules are transported from the cell body anterogradely down processes. Scale bars (a), (b), (c) $-2 \mu \mathrm{m}, \mathrm{c}-1 \mu \mathrm{m}$. Reproduced from (Smith et al. 2015)

mucocytes, and peptidergic sensory secretory cells. It may have had cells that secreted both mucous and a peptide used for intercellular communication, as appears to be the case for type 2 gland cells in Trichoplax. Regulated secretion by the sensory cells was calcium-dependent and mediated by proteins homologous to secretory proteins of neurons and endocrine cells of bilaterians. The epithelial cells were joined by adherens junctions and likely were contractile. The different cell types probably were arranged in distinctive patterns within the epithelium appropriate to their roles in feeding. Patterning may have been accomplished by the many developmental genes shared by Placozoa, Cnidaria, and Bilateria (DuBuc et al. 2019; Srivastava et al. 2008).

Some have argued that the ancestor of animals with internal digestive systems may have been a pelagic filter-feeder that was shaped like a sac with an internal digestive cavity and an opening to the outside for ingesting food and expelling waste (Haeckel 1874; reviewed by Nielsen 2008; Syed and Schierwater 2002b). We favor an alternative hypothesis (Arendt et al. 2015; Nielsen 2008; Schierwater 2005; Sperling and Vinther 2010; Syed and Schierwater 2002a, b) that the ancestor was a benthic, placozoan-like organism that digested food on its exterior surface. If it was able to feed upon cyanobacteria and microalgae, as extant Placozoa can (Pearse and Voigt 2007; Smith et al. 2015), it could have found sustenance in the microbial mats that covered the seafloor in photic areas of the oceans in the Neoproterozoic period during which Metazoa are thought to have evolved (Droser and Gehling 2015; Erwin 2015; Fedonkin 2003; Gehling et al. 2005; Gingras et al. 2011; Hoehler et al. 2001; Ivantsov 2013; Peterson et al. 2012; Xiao and Laflamme 2009). Cyanobacteria and algae, which are oxygenic photosynthesizers, occupied the top layer of the mats.

The oldest macroscopic fossils that are widely accepted as representing animals are found in association with microbial mats in Ediacaran sediments (575-542 Ma) (Erwin 2015; Fedonkin 2003; Gehling et al. 2005; Gingras et al. 2011; Hoehler et al. 2001; Ivantsov 2013; Peterson et al. 2012; Xiao and Laflamme 2009). Some of these fossils are thought to represent stem cnidarians and bilaterians with internal digestive systems, muscles, and nervous systems while others had body plans very different from any extant animal. Dickinsoniids had flattened, metameric bodies with a distinct 

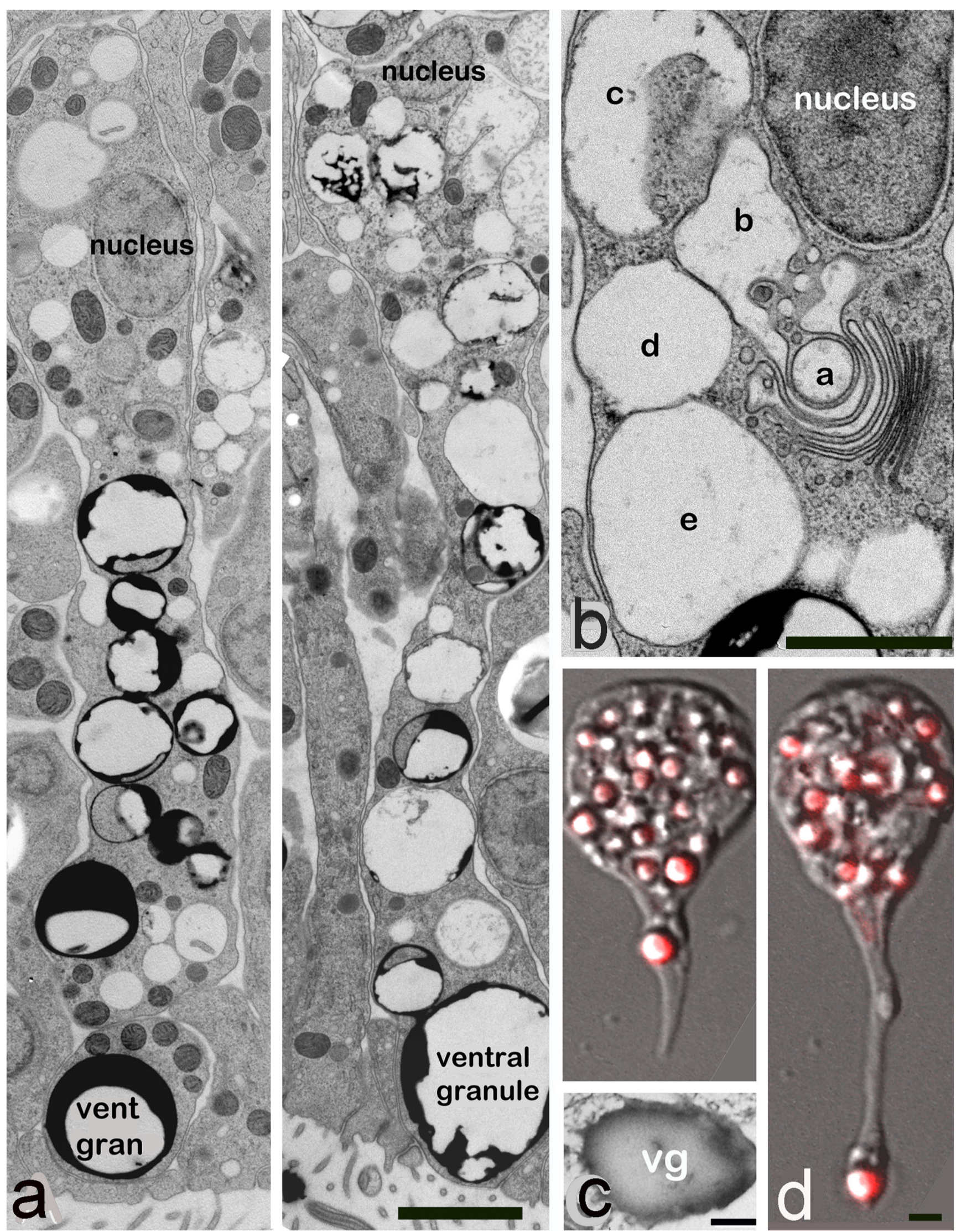

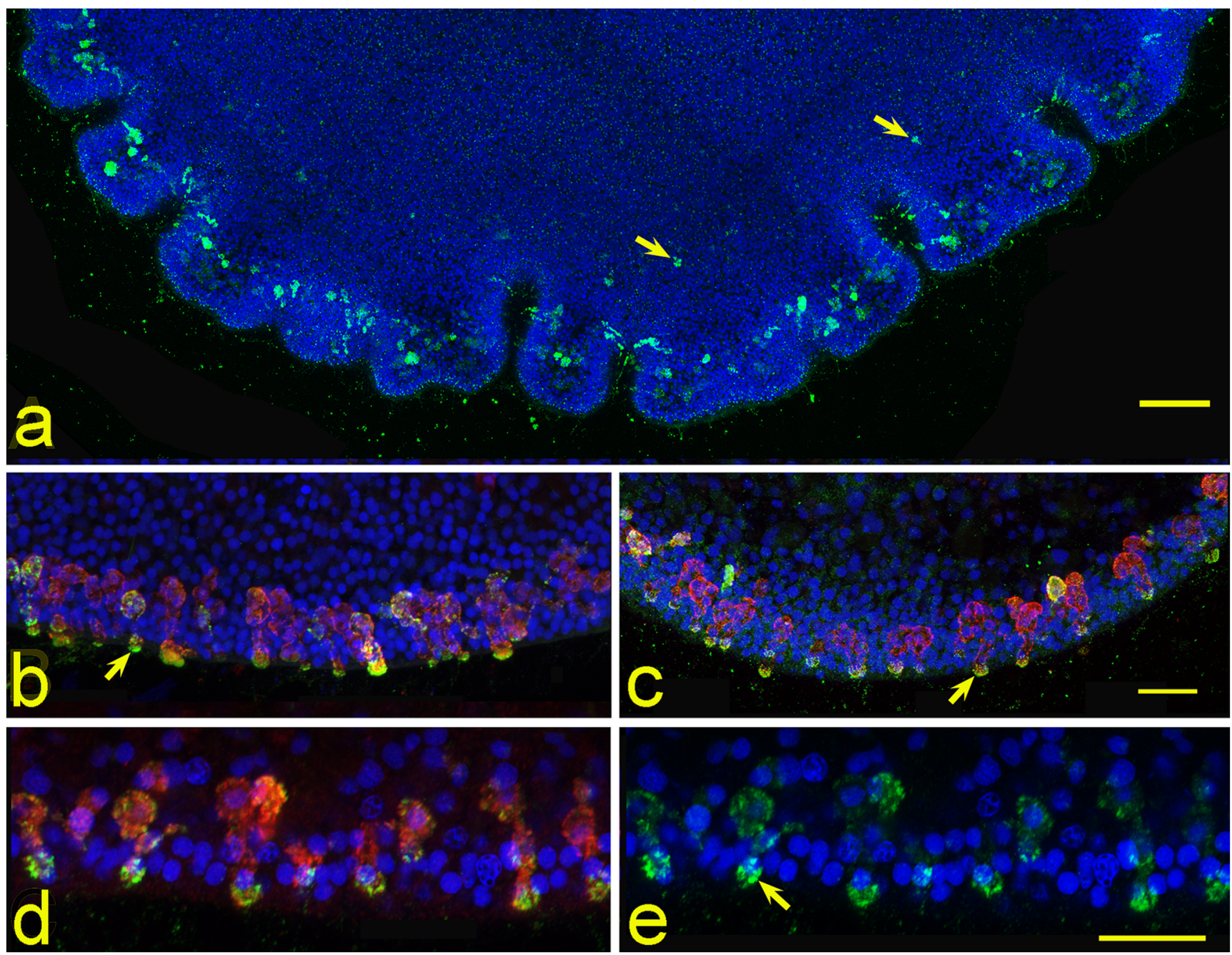

Fig. 5 Immunofluorescence localization of peptides and a neurosecretory protein in Trichoplax. a Enface view of a Trichoplax labeled with antiYPFFamide. Labeled cells are prevalent around the edge but also present, although dimmer, further toward the center (arrows). b, c Double-labeling for YPFFamide (b; green) or TaELP propeptide (c; green) and complexin (red) in secretory cells near the edge of the animal. Complexin staining

anterior and posterior, but no evidence of a mouth or internal digestive system. They ranged in size from less than a centimeter to over a meter. Although their phylogenetic position has been debated, the recent discovery that they contained cholesteroids provides strong evidence that they were animals (Bobrovskiy et al. 2018). Their body fossils often are associated with a series of size-matched imprints that some have interpreted as evidence that they digested or decomposed the underlying microbial mat and were capable of intermittent autonomous movement (Droser and Gehling 2015; Fedonkin 2003; Gehling et al. 2005; Ivantsov 2011). Sperling and Vinther (2010) have argued that Dickinsoniids may represent stem placozoans or an extinct lineage that arose after Placazoa. The apparent complexity of these Ediacaran animals suggests that their lineages originated much earlier. Molecular clock analyses put the origin of Metazoa $>800 \mathrm{Ma}$ extends throughout the cells while YPFFamide and TaELP propeptide staining is concentrated in cell endings at the exterior surface (arrows). d, e Enlarged and color-separated view (e) shows granular-labeling for YPFFamide. Scale bars, $\mathbf{a}-50 \mu \mathrm{m} ; \mathbf{b}, \mathbf{c}-10 \mu \mathrm{m}$. Reproduced from (Senatore et al. 2017)

and the origin of the clade that includes Placozoa, Cnidaria, and Bilateria $\sim 710 \mathrm{Ma}$ (Erwin et al. 2011). That the Ediacaran fossils are found in association with microbial mats supports the idea that their ancestors likely were benthic.

A benthic animal that fed by digesting food underneath its lower surface would benefit by being able to move, sense food, and coordinate the activities of its cells as appropriate for seeking food or eating it. The work we have reviewed here is beginning to provide a picture of how this can be accomplished in an animal with only a small number of morphologically distinct cell types and no nervous system. Future work comparing the functional and regulatory/ developmental genes in Trichoplax and other animals can be expected to provide insight into the evolution of differentiated cell types and how complex body plans arose from simpler ones. 


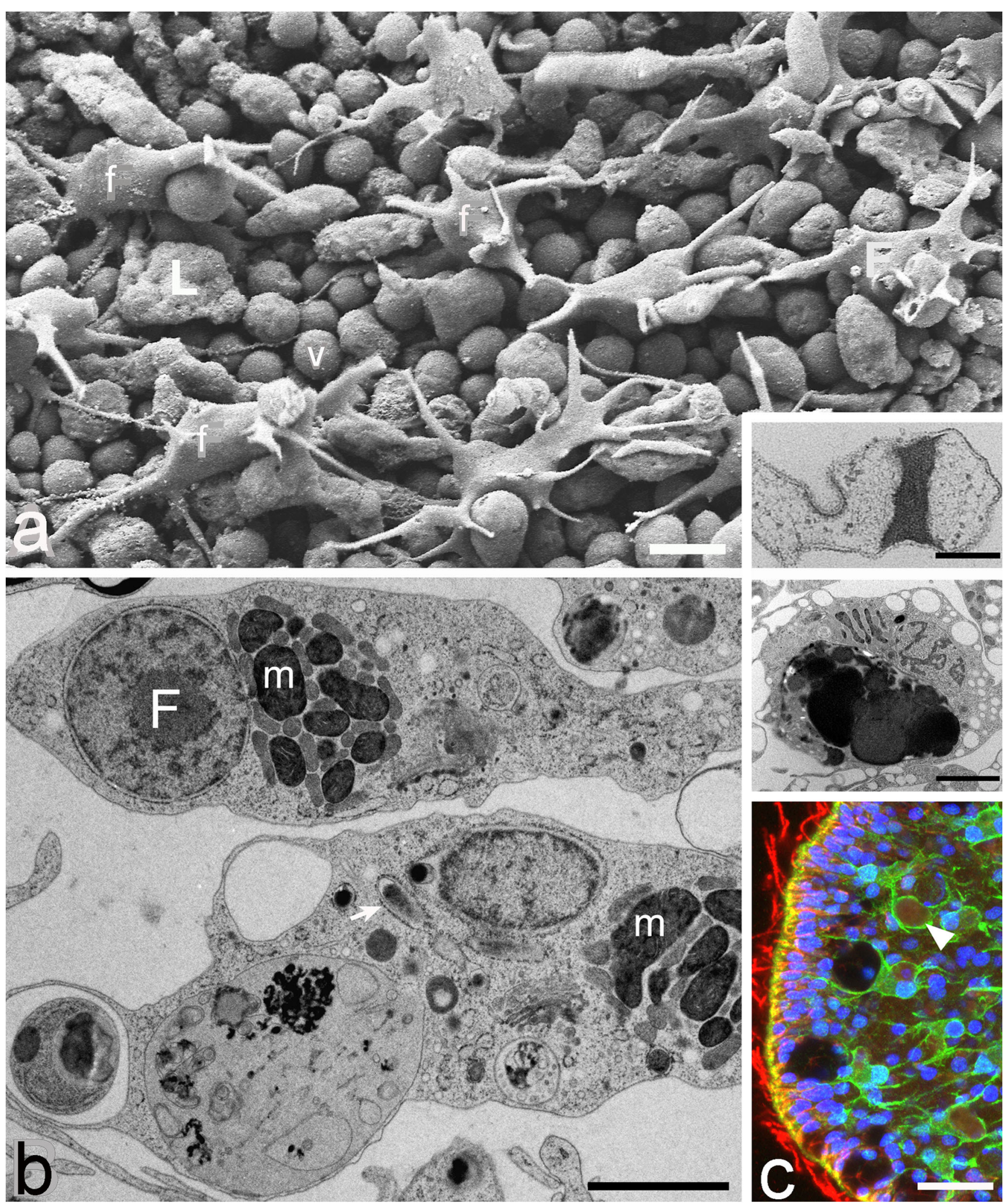

Fig. 6 Fiber cells. a SEM image of interior exposed by removal of the dorsal epithelium. Regularly spaced fiber cells (F) extend multiple tapering processes around the cell bodies of underlying VEC (v). A lipophil (L) is identified by its content of granules. The TEM inset shows a dense septal junction connecting the processes of two fiber cells. The membrane is continuous across the septum. b TEM micrographs show characteristic inclusions of fiber cell bodies: clusters of mitochondria $(\mathrm{m})$ interspersed

with smaller inclusions and large electron dense inclusion (inset). (c) Immunofluorescence staining for an unidentified protein that is highly expressed in fiber cells (green). Anti-tubulin (red) stains cilia around the edge. Nuclei are blue. Scale bars, $\mathbf{a}-5 \mu \mathrm{m}$, (a) inset $-0.5 \mu \mathrm{m}, \mathbf{b}-10 \mu \mathrm{m}$, and (b) inset-2 $\mu \mathrm{m}$. Reproduced from (Smith et al. 2014) copyright 2014 with permission from Elsevier 
Acknowledgments We thank Dr. Adriano Senatore for sharing information about Trichoplax and Ctenophora transcriptomes and Dr. Thomas S. Reese for helpful discussions and comments on this manuscript.

Funding This work was supported by the Intramural Research Program of the National Institutes of Health, National Institute of Neurological Disorders and Stroke.

\section{Compliance with ethical standards}

Conflict of interest The authors declare that they have no conflict of interest.

Ethical approval This article does not contain any studies with human participants or animals performed by any of the authors.

Open Access This article is distributed under the terms of the Creative Commons Attribution 4.0 International License (http:// creativecommons.org/licenses/by/4.0/), which permits unrestricted use, distribution, and reproduction in any medium, provided you give appropriate credit to the original author(s) and the source, provide a link to the Creative Commons license, and indicate if changes were made.

\section{References}

Adams JC (2013) In: Keely F, Mecham R (eds) Evolution of extracellular matrix. Springer, Berlin Heidelberg, pp 1-25

Anderson PAV, Thompson LF, Moneypenny CG (2004) Evidence for a common pattern of peptidergic innervation of cnidocytes. Biol Bull 207(2):141-146. https://doi.org/10.2307/1543588

Arendt D, Benito-Gutierrez E, Brunet T, Marlow H (2015) Gastric pouches and the mucociliary sole: setting the stage for nervous system evolution. Philos Trans R Soc Lond Ser B Biol Sci 370(1684): 20150286. https://doi.org/10.1098/rstb.2015.0286

Armon, S., Bull, M. S., Aranda-Diaz, A., \& Prakash, M. (2018). Ultrafast epithelial contractions provide insights into contraction speed limits and tissue integrity. Proc Natl Acad Sci, 201802934. https://doi.org/ $10.1073 /$ pnas. 1802934115

Assmann M, Kuhn A, Dürrnagel S, Holstein TW, Gründer S (2014) The comprehensive analysis of DEG/ENaC subunits in Hydra reveals a large variety of peptide-gated channels, potentially involved in neuromuscular transmission. BMC Biol 12(1):84. https://doi.org/10. 1186/s12915-014-0084-2

Bakshani, C. R., Morales-Garcia, A. L., Althaus, M., Wilcox, M. D., Pearson, J. P., Bythell, J. C., \& Burgess, J. G. (2018). Evolutionary conservation of the antimicrobial function of mucus: a first defence against infection. Npj Biofilms and Microbiomes. Nature Publishing Group. https://doi.org/10.1038/s41522-0180057-2

Bobrovskiy I, Hope JM, Ivantsov A, Nettersheim BJ, Hallmann C, Brocks JJ (2018) Ancient steroids establish the Ediacaran fossil Dickinsonia as one of the earliest animals. Science 361(6408): 1246-1249. https://doi.org/10.1126/science.aat7228

Brunet T, King N (2017) The origin of animal multicellularity and cell differentiation. Developmental Cell. Elsevier. https://doi.org/10. 1016/j.devcel.2017.09.016

Buchholz K, Ruthmann A (1995) The mesenchyme-like layer of the fiber cells of Trichoplax adhaerens (Placozoa), a Syncytium $Z$ Naturforsch, 50 c, 282-285

Bumann D, Puls G (1997) The ctenophore Mnemiopsis leidyi has a flowthrough system for digestion with three consecutive phases of extracellular digestion. Physiol Zool 70(1):1-6 Retrieved from http://www.ncbi.nlm.nih.gov/pubmed/9231370

Cavalier-Smith T (2016) Origin of animal multicellularity: precursors, causes, consequences - the choanoflagellate/sponge transition, neurogenesis and the Cambrian explosion. Philosophical Transactions of the Royal Society of London B: Biological Sciences, 372(1713)

Conzelmann M, Jékely G (2012) Antibodies against conserved amidated neuropeptide epitopes enrich the comparative neurobiology toolbox. EvoDevo 3(1):23. https://doi.org/10.1186/2041-9139-3-23

Dayel MJ, Alegado RA, Fairclough SR, Levin TC, Nichols SA, McDonald K, King N (2011) Cell differentiation and morphogenesis in the colony-forming choanoflagellate Salpingoeca rosetta. Dev Biol 357(1):73-82. https://doi.org/10.1016/j.ydbio.2011.06.003

Dayel MJ, King N (2014) Prey capture and phagocytosis in the choanoflagellate Salpingoeca rosetta. PLoS One 9(5):e95577. https://doi.org/10.1371/journal.pone.0095577

Dias RO, Cardoso C, Pimentel AC, Damasceno TF, Ferreira C, Terra WR (2018) The roles of mucus-forming mucins, peritrophins and peritrophins with mucin domains in the insect midgut. Insect Mol Biol 27(1):46-60. https://doi.org/10.1111/imb.12340

Dohrmann M, Wörheide G (2013) Novel scenarios of early animal evolution-is it time to rewrite textbooks? In Integrative and Comparative Biology (Vol. 53, pp. 503-511). Oxford University Press. https://doi.org/10.1093/icb/ict008

Droser ML, Gehling JG (2015) The advent of animals: the view from the Ediacaran. Proc Natl Acad Sci 112(16):4865-4870. https://doi.org/ 10.1073/pnas.1403669112

DuBuc TQ, Ryan J, Martindale MQ (2019) "Dorsal-ventral" genes are part of an ancient axial patterning system: evidence from Trichoplax adhaerens (Placozoa). Mol Biol Evol. https://doi.org/10.1093/ molbev/msz025

Dunn CW, Hejnol A, Matus DQ, Pang K, Browne WE, Smith SA et al (2008) Broad phylogenomic sampling improves resolution of the animal tree of life. Nature 452(7188):745-749. https://doi.org/10. 1038/nature06614

Eitel M, Francis WR, Varoqueaux F, Daraspe J, Osigus H-J, Krebs S et al (2018) Comparative genomics and the nature of placozoan species. PLoS Biol 16(7):e2005359. https://doi.org/10.1371/journal.pbio. 2005359

Eitel M, Guidi L, Hadrys H, Balsamo M, Schierwater B (2011) New insights into placozoan sexual reproduction and development. PLoS One 6(5):e19639. https://doi.org/10.1371/journal.pone. 0019639

Ereskovsky AV, Tokina DB, Bézac C, Boury-Esnault N (2007) Metamorphosis of cinctoblastula larvae (Homoscleromorpha, porifera). J Morphol 268(6):518-528. https://doi.org/10.1002/jmor. 10506

Erwin DH (2015) Early metazoan life: divergence, environment and ecology. Philos Trans R Soc Lond Ser B Biol Sci 370(1684):20150036. https://doi.org/10.1098/rstb.2015.0036

Erwin DH, Laflamme M, Tweedt SM, Sperling EA, Pisani D, Peterson KJ (2011) The Cambrian conundrum: early divergence and later ecological success in the early history of animals. Science (New York, NY) 334(6059):1091-1097. https://doi.org/10.1126/science. 1206375

Fankboner PV, Columbia B (2002) Digestive system of invertebrates. Life Sci, (1998), 1-6. https://doi.org/10.1038/npg.els.0003645

Fedonkin MA (2003) The origin of the Metazoa in the light of the Proterozoic fossil record. Paleontological Research 7(1):9-41. https://doi.org/10.2517/prpsj.7.9

Francis WR, Eitel M, Vargas S, Adamski M, Haddock SHD, Krebs S, ... Wörheide G (2017) The genome of the contractile demosponge Tethya wilhelma and the evolution of metazoan neural signalling pathways. bioRxiv, preprint. https://doi.org/10.1101/120998 
Fricker LD (2005) Neuropeptide-processing enzymes: applications for drug discovery. AAPS J 7(2):449-455. https://doi.org/10.1208/ aapsj070244

Furness JB, Stebbing MJ (2018) The first brain: species comparisons and evolutionary implications for the enteric and central nervous systems. Neurogastroenterol Motil 30(2):e13234. https://doi.org/10. 1111/nmo.13234

Gehling JG, Droser ML, Jensen SR, Runnegar BN (2005) Ediacaran organisms: relating form and function. In Evolving form and function: fossils and development: proceedings of a Symposium Honouring Adolf Seilacher (pp. 43-67)

Gingras M, Hagadorn JW, Seilacher A, Lalonde SV, Pecoits E, Petrash D, Konhauser KO (2011) Possible evolution of mobile animals in association with microbial mats. Nat Geosci 4(6):372-375. https://doi. org/10.1038/ngeo1142

Goldberg WM, Taylor GT (1989) Cellular structure and ultrastructure of the black coral Antipathes aperta: 1. Organization of the tentacular epidermis and nervous system. J Morphol 202(2):239-253. https:// doi.org/10.1002/jmor.1052020210

Grell KG (1971) Trichoplax adhaerens und die Entstehung der Metazoen. Naturw Rundsch 24(4):160-161

Grell KG, Benwitz G (1971) Die Ultrastruktur von Trichoplax adhaerens F.E. Schulze. Cytobiol 4:216-240. Cytobiologie, 4, 216-240

Grell KG, Benwitz G (1974) Spezifische Verbindungsstrukuren der Faserzellen von Trichoplax ad- haerensF.E. Schulze. Z. Naturforsch., 29c, 790. https://doi.org/10.1002/jmor.10922

Grell KG, Ruthmann A (1991) Placozoa. In: Harrison FW, Westfall JA (eds) Microscopic anatomy of invertebrates. Wiley-Liss, New York, pp 13-27 Retrieved from http://download.springer.com/static/pdf/ 813/art\%3A10.1007\%2Fs00427-004-0390-8.pdf?auth66= 1363711205 d5c9623bde6301d7ab57239eaefe9a93\&ext=.pdf

Grimmelikhuijzen CJP, Graff D, Koizumi O, Westfall JA, McFarlane ID (1991) Neuropeptides in coelenterates: a review. Hydrobiologia 216-217(1):555-563. https://doi.org/10.1007/BF00026513

Guidi L, Eitel M, Cesarini E, Schierwater B, Balsamo M (2011) Ultrastructural analyses support different morphological lineages in the phylum placozoa Grell, 1971. J Morphol 272(3):371-378. https://doi.org/10.1002/jmor.10922

Haeckel E (1874) Die Gastraea-Theorie, die phylogenetische classification des Thierreiches und die Homologie der Keimblatter. Jena Z Naturwiss, 8, 1-55

Harrison F, Westfall JA (1991) In: Harrison FW, Westfall JA (eds) Microscopic anatomy of invertebrates. Volume 2. Placozoa, Porifera, Cnidaria, and Ctenophora. Wiley-Liss, Inc., NY

Hernandez-Nicaise M-L (1991) Ctenophora. In: Harrison JA, Westfall FW (eds) Microscopic anatomy of invertebrates. Volume 2. WileyLiss, New York, pp 359-418

Heyland A, Croll R, Goodall S, Kranyak J, Wyeth R (2014) Trichoplax adhaerens, an enigmatic basal metazoan with potential. Methods Mol Biol 1128:45-61. https://doi.org/10.1007/978-1-62703-974-14

Hoehler TM, Bebout BM, Des Marais DJ (2001) The role of microbial mats in the production of reduced gases on the early earth. Nature 412(6844):324-327. https://doi.org/10.1038/35085554

Hook V, Funkelstein L, Lu D, Bark S, Wegrzyn J, Hwang S-R (2008) Proteases for processing proneuropeptides into peptide neurotransmitters and hormones. Annu Rev Pharmacol Toxicol 48:393-423. https://doi.org/10.1146/annurev.pharmtox.48.113006.094812

Ichikawa M, Ichikawa A, Kidokoro S (1987) Secretory process of mucussecreting cells in mouse colonic mucosa studied by rapid freezing and freeze-substitution. J Electron Microsc 36(3):117-127 Retrieved from http://www.ncbi.nlm.nih.gov/pubmed/3625086

Ivantsov a Y (2011) Feeding traces of proarticulata - the Vendian metazoa. Paleontol J 45(3):237-248. https://doi.org/10.1134/ S0031030111030063
Ivantsov a Y (2013) Trace fossils of precambrian metazoans "Vendobionta" and "Mollusks.". Stratigr Geol Correl 21(3):252264. https://doi.org/10.1134/S0869593813030039

Jackson AM, Buss LW (2009) Shiny spheres of placozoans ( Trichoplax ) function in anti-predator defense. Invertebr Biol 128(3):205-212. https://doi.org/10.1111/j.1744-7410.2009.00177.x

Jager M, Chiori R, Alié A, Dayraud C, Quéinnec E, Manuel M (2011) New insights on ctenophore neural anatomy: immunofluorescence study in Pleurobrachia pileus (Müller, 1776). J Exp Zool B Mol Dev Evol 316B(3):171-187. https://doi.org/10.1002/jez.b.21386

Jékely G (2013) Global view of the evolution and diversity of metazoan neuropeptide signaling. Proc Natl Acad Sci U S A 110(21):87028707. https://doi.org/10.1073/pnas.1221833110

Jouiaei M, Yanagihara A, Madio B, Nevalainen T, Alewood P, Fry B et al (2015) Ancient venom systems: a review on Cnidaria toxins. Toxins 7(6):2251-2271. https://doi.org/10.3390/toxins 7062251

Kaelberer MM, Buchanan KL, Klein ME, Barth BB, Montoya MM, Shen X, Bohórquez DV (2018) A gut-brain neural circuit for nutrient sensory transduction. Science 361(6408):eaat5236. https://doi.org/ 10.1126/science.aat5236

Kim H-M, Weber JA, Lee N, Park SG, Cho YS, Bhak Y, ... Yum S (2018) The jellyfish genome sheds light on the early evolution of active predation. bioRxiv, 449082. https://doi.org/10.1101/449082

King N (2004) The unicellular ancestry of animal development. Dev Cell Retrieved from https://doi.org/10.1016/j.devcel.2004.08.010

King N, Rokas A (2017) Embracing uncertainty in reconstructing early animal evolution. Curr Biol 27(19):R1081-R1088. https://doi.org/ 10.1016/J.CUB.2017.08.054

King N, Westbrook MJ, Young SL, Kuo A, Abedin M, Chapman J et al (2008) The genome of the choanoflagellate Monosiga brevicollis and the origin of metazoans. Nature 451(7180):783-788 Retrieved from http://www.nature.com/nature/journal/v451/ n7180/full/nature06617.html

Knoll AH (2011) The multiple origins of complex multicellularity. Annu Rev Earth Planet Sci 39(1):217-239. https://doi.org/10.1146/ annurev.earth.031208.100209

Koizumi O (2016) Origin and evolution of the nervous system considered from the diffuse nervous system of cnidarians. In: The Cnidaria, past, present and future. Springer International Publishing, Cham, pp 73-91. https://doi.org/10.1007/978-3-319-31305-4_6

Koizumi O, Itazawa M, Mizumoto H, Minobe S, Javois LC, Grimmelikhuijzen CJP, Bode HR (1992) Nerve ring of the hypostome in Hydra. I. Its structure, development, and maintenance. J Comp Neurol 326(1):7-21. https://doi.org/10.1002/cne.903260103

Krishnan A, Schiöth HB (2015) The role of G protein-coupled receptors in the early evolution of neurotransmission and the nervous system. J Exp Biol 218(Pt 4:562-571. https://doi.org/10.1242/jeb.110312

Kumar D, Mains RE, Eipper BA (2016) 60 years of POMC: from POMC and $\alpha$-MSH to PAM, molecular oxygen, copper, and vitamin C. J Mol Endocrinol 56(4):T63-T76. https://doi.org/10.1530/JME-150266

Lang T, Hansson GC, Samuelsson T (2007) Gel-forming mucins appeared early in metazoan evolution. Proc Natl Acad Sci U S A 104(41):16209-16214. https://doi.org/10.1073/pnas.0705984104

Lang T, Klasson S, Larsson E, Johansson MEV, Hansson GC, Samuelsson T (2016) Searching the evolutionary origin of epithelial mucus protein components-mucins and FCGBP. Mol Biol Evol 33(8):1921-1936. https://doi.org/10.1093/molbev/msw066

Leys S, Eerkes-Medrano D (2006) Feeding in a calcareous sponge: particle uptake by pseudopodia. Biol Bull 211(2):157-171 Retrieved from http://www.biolbull.org/cgi/content/full/211/2/157?view= long\&pmid=17062875

Leys SP, Degnan BM (2001) Cytological basis of photoresponsive behavior in a sponge larva. Biol Bull 201(3):323-338 Retrieved from http://www.ncbi.nlm.nih.gov/pubmed/11751245 
Liévin-Le Moal V, Servin AL (2006) The front line of enteric host defense against unwelcome intrusion of harmful microorganisms: mucins, antimicrobial peptides, and microbiota. Clin Microbiol Rev 19(2):315-337. https://doi.org/10.1128/CMR.19.2.315-337.2006

Luxmi R, Blaby-Haas C, Kumar D, Rauniyar N, King SM, Mains RE et al (2018) Proteases shape the chlamydomonas secretome: comparison to classical neuropeptide processing machinery. Proteomes 6(4):36. https://doi.org/10.3390/proteomes6040036

Mackie GO, Singla CL (1983) Studies on hexactinellid sponges. I. Histology of Rhabdocalyptus dawsoni (Lambe, 1873). Philos Trans R Soc Lond B Biol Sci 301(1107):365-400. https://doi.org/ 10.1098/rstb.1983.0028

Mah JL, Christensen-Dalsgaard KK, Leys SP (2014) Choanoflagellate and choanocyte collar-flagellar systems and the assumption of homology. Evol Dev 16(1):25-37. https://doi.org/10.1111/ede.12060

Mains RE, Park LP, Eipper BA (1986) Inhibition of peptide amidation by disulfiram and diethyldithiocarbamate. J Biol Chem 261(26): 11938-11941

Marlow HQ, Srivastava M, Matus DQ, Rokhsar D, Martindale MQ (2009) Anatomy and development of the nervous system of Nematostella vectensis, an anthozoan cnidarian. Dev Neurobiol 69(4):235-254. https://doi.org/10.1002/dneu.20698

Mayorova TD, Smith CL, Hammar K, Winters CA, Pivovarova NB, Aronova MA et al (2018a) Cells containing aragonite crystals mediate responses to gravity in Trichoplax adhaerens (Placozoa), an animal lacking neurons and synapses. PLoS One 13(1):e0190905. https://doi.org/10.1371/journal.pone.0190905

Mayorova TD, Smith CL, Reese TS (2018b) Secretory cells in the digestive epithelium of Trichoplax adhaerens, an animal that feeds by external digestion. Society for Neuroscience Abstract, 282.15

Mayorova T, Kosevich I (2013) FMRF-amide immunoreactivity pattern in the planula and colony of the hydroid Gonothyraea loveni. Zoology 116(1):9-19. https://doi.org/10.1016/J.ZOOL.2012.07.002

Monk T, Paulin MG (2014) Predation and the origin of neurones. Brain Behav Evol 84(4):246-261. https://doi.org/10.1159/000368177

Moroz LL, Kocot KM, Citarella MR, Dosung S, Norekian TP, Povolotskaya IS et al (2014) The ctenophore genome and the evolutionary origins of neural systems. Nature 510:109-114. https://doi. org/10.1038/nature13400

Moroz LL, Kohn AB (2016) Independent origins of neurons and synapses: insights from ctenophores. Philos Trans R Soc Lond Ser B Biol Sci 371(1685):20150041. https://doi.org/10.1098/rstb.2015.0041

Navarrete del Toro MA, García-Carreño F (2018). The toolbox for protein digestion in decapod crustaceans: a review. Rev Aquac, pp. 1-17. https://doi.org/10.1111/raq.12276

Nielsen C (2008) Six major steps in animal evolution: are we derived sponge larvae? Evol Dev 10(2):241-257. Retrieved from http:// www3.interscience.wiley.com/cgi-bin/fulltext/119422110/ HTMLSTART

Nielsen C (2012) Animal evolution: interrelationships of the living phyla (3rd.). Oxford University Press, Oxford. https://doi.org/10.1093/icb/ ict005

Nikitin M (2014) Bioinformatic prediction of Trichoplax adhaerens regulatory peptides. Gen Comp Endocrinol 212:145-155. https://doi. org/10.1016/j.ygcen.2014.03.049

Pandol SJ (2010) The exocrine pancreas. Morgan \& Claypool Life Sciences, San Rafael. https://doi.org/10.4199/ C00026ED1V01Y201102ISP014

Pearse VB, Voigt O (2007) Field biology of placozoans (Trichoplax): distribution, diversity, biotic interactions. Integr Comp Biol 47(5): 677-692. https://doi.org/10.1093/icb/icm015

Peterson J, Mcpeek A, Evans AD (2012) Paleontological society tempo and mode of early animal evolution: inferences from rocks, Hox, and molecular clocks author ( $\mathrm{s}$ ): Kevin J . Peterson, Mark A . McPeek and David A . D . Evans reviewed work ( s ): published by: paleontological society co. Paleobiology, 31(2), 36-55
Pett W, Adamski M, Adamska M, Francis WR, Eitel M, Pisani D, Wörheide G (2019) The role of homology and orthology in the phylogenomic analysis of metazoan gene content. Mol Biol Evol 36(4):643-649. https://doi.org/10.1093/molbev/msz013

Ringrose JH, van den Toorn HWPP, Eitel M, Post H, Neerincx P, Schierwater B et al (2013) Deep proteome profiling of Trichoplax adhaerens reveals remarkable features at the origin of metazoan multicellularity. Nat Commun 4(May 2012):1408. https://doi.org/ $10.1038 /$ ncomms 2424

Ruthmann A, Behrendt G, Wahl R (1986) The ventral epithelium of Trichoplax adhaerens (Placozoa): cytoskeletal structures, cell contacts and endocytosis. Zoomorphology 106(2):115-122. https://doi. org/10.1007/BF00312113

Ryan JF, Pang K, Schnitzler CE, Nguyen A-D, Moreland RT, Simmons DK et al (2013) The genome of the ctenophore Mnemiopsis leidyi and its implications for cell type evolution. Science (New York, NY) 342(6164):1242592. https://doi.org/10.1126/science.1242592

Sandoz D, Nicolas G, Laine MC (1985) Two mucous cell types revisited after quick-freezing and cryosubstitution. Biol Cell 54(1):79-88. https://doi.org/10.1111/j.1768-322X.1985.tb00382.x

Schierwater B (2005) My favorite animal, Trichoplax adhaerens. Bioessays 27(12):1294-1302. https://doi.org/10.1002/bies.20320

Schulze FE (1883) Trichoplax adhaerens, nov. gen., nov. spec. Zool Anz 6:92-97

Schulze FE (1891) Uber Trichoplax adhaerens. Phys Abh Kgl Acad Wiss Berl, 1-23

Sebé-Pedrós A, Chomsky E, Pang K, Lara-Astiaso D, Gaiti F, Mukamel $\mathrm{Z}$ et al (2018) Early metazoan cell type diversity and the evolution of multicellular gene regulation. Nat Ecol Evol 2(June):1176-1188. https://doi.org/10.1038/s41559-018-0575-6

Senatore A, Raiss H, Le P (2016) Physiology and evolution of voltagegated calcium channels in early diverging animal Phyla: Cnidaria, Placozoa, Porifera and Ctenophora. Front Physiol 7(November):126. https://doi.org/10.3389/fphys.2016.00481

Senatore A, Reese TS, Smith CL (2017) Neuropeptidergic integration of behavior in Trichoplax adhaerens, an animal without synapses. J Exp Biol 220(18):3381-3390. https://doi.org/10.1242/JEB.162396

Signorovitch AY, Dellaporta SL, Buss LW (2005) Molecular signatures for sex in the Placozoa. Proc Natl Acad Sci U S A 102(43):1551815522. https://doi.org/10.1073/pnas.0504031102

Signorovitch AY, Dellaporta SL, Buss LW (2006) Caribbean Placozoan phylogeography. Biol Bull 211(2):149-156 Retrieved from http:// www.biolbull.org/content/211/2/149.full

Simion P, Philippe H, Baurain D, Jager M, Richter DJ, Di Franco A et al (2017) A large and consistent phylogenomic dataset supports sponges as the sister group to all other animals. Curr Biol 27(7): 958-967. https://doi.org/10.1016/j.cub.2017.02.031

Smith CL, Pivovarova N, Reese TS (2015) Coordinated feeding behavior in Trichoplax, an animal without synapses. PLoS One 10(9): e0136098. https://doi.org/10.1371/journal.pone.0136098

Smith CL, Reese TS (2016) Adherens junctions modulate diffusion between epithelial cells in Trichoplax adhaerens. Biol Bull, 231(3). https://doi.org/10.1086/691069

Smith CL, Reese TS, Govezensky T, Barrio RA (2019) Coherent directed movement toward food modeled in Trichoplax, a ciliated animal lacking a nervous system. Proc Natl Acad Sci, 201815655. https:// doi.org/10.1073/PNAS.1815655116

Smith CL, Varoqueaux F, Kittelmann M, Azzam RN, Cooper B, Winters CA et al (2014) Novel cell types, neurosecretory cells, and body plan of the early-diverging metazoan Trichoplax adhaerens. Curr Biol 24(14):1565-1572. https://doi.org/10.1016/j.cub.2014.05.046

Sperling EA, Vinther J (2010) A placozoan affinity for Dickinsonia and the evolution of late Proterozoic metazoan feeding modes. Evol Dev 12(2):201-209. https://doi.org/10.1111/j.1525-142X.2010.00404.x

Srivastava M, Begovic E, Chapman J, Putnam NH, Hellsten U, Kawashima $\mathrm{T}$ et al (2008) The Trichoplax genome and the nature 
of placozoans. Nature 454(7207):955-960. https://doi.org/10.1038/ nature 07191

Srivastava M, Simakov O, Chapman J, Fahey B, Gauthier MEA, Mitros $\mathrm{T}, \ldots$ Rokhsar DS (2010) The Amphimedon queenslandica genome and the evolution of animal complexity. Nature Retrieved from http://www.ncbi.nlm.nih.gov/pubmed/20686567

Syed T, Schierwater B (2002a) The evolution of the Placozoa: a new morphological model. Senckenb Lethaea 82(1):315-324. https:// doi.org/10.1007/BF03043791

Syed T, Schierwater B (2002b) Trichoplax adhaerens: discovered as a missing link, forgotten as a hydrozoan, re-discovered as a key to Metozoan evolution. Vie Milieu 52(4):177-187. https://doi.org/ $10.1002 /$ jrs. 2103

Takashima S, Gold D, Hartenstein V (2013) Stem cells and lineages of the intestine: a developmental and evolutionary perspective. Dev Genes Evol 223(1-2):85-102. https://doi.org/10.1007/s00427-012-0422-8

Tang J (1979) Evolution in the structure and function of carboxyl proteases, 26(2). Retrieved from https://link.springer.com/content/ pdf/10.1007\%2FBF00232887.pdf

Tang J, Wong RNS (1987) Evolution in the structure and function of aspartic proteases. J Cell Biochem 33(1):53-63. https://doi.org/10. $1002 /$ jcb. 240330106

Ueda T, Koya S, Maruyama YK (1999) Dynamic patterns in the locomotion and feeding behaviors by the placozoan Trichoplax adhaerens. Bio Systems 54(1-2):65-70. https://doi.org/10.1016/S03032647(99)00066-0

Varoqueaux F, Williams EA, Grandemange S, Schierwater B, Jeke G, Fasshauer Correspondence D (2018) High cell diversity and complex peptidergic signaling underlie Placozoan behavior. Curr Biol 28:3495-3501. https://doi.org/10.1016/j.cub.2018.08.067
Voigt O, Collins AG, Pearse VB, Pearse JS, Ender A, Hadrys H, Schierwater B (2004) Placozoa - no longer a phylum of one. Curr Biol Retrieved from http://www.sciencedirect.com/science/article/ pii/S0960982204008413

Watanabe H, Fujisawa T, Holstein TW (2009) Cnidarians and the evolutionary origin of the nervous system, $51 \S$. Blackwell Publishing Asia https://doi.org/10.1111/j.1440-169X.2009.01103.x

Whelan NV, Kocot KM, Moroz TP, Mukherjee K, Williams P, Paulay G et al (2017) Ctenophore relationships and their placement as the sister group to all other animals. Nat Ecol Evol 1(11):1737-1746. https://doi.org/10.1038/s41559-017-0331-3

Whelan NV, Kocot KM, Moroz LL, Halanych KM (2015) Error, signal, and the placement of Ctenophora sister to all other animals. Proc Natl Acad Sci USA. https://doi.org/10.1073/pnas.1503453112

Wong YY (2018) Deep sequencing and annotation of the Trichoplax adhaerens mRNA transcriptome identifies novel genes and a rich repertoire of neural signaling machinery, providing insight into nervous system evolution. University of Toronto

Xiao S, Laflamme M (2009) On the eve of animal radiation: phylogeny, ecology and evolution of the Ediacara biota. Trends Ecol Evol 24(1): 31-40. https://doi.org/10.1016/j.tree.2008.07.015

Yonge CM (1937) Evolution and adaptation in the digestive system of the Metazoa. Biol Rev 12(1):87-114. https://doi.org/10.1111/j.1469185X.1937.tb01223.X

Publisher's note Springer Nature remains neutral with regard to jurisdictional claims in published maps and institutional affiliations. 